\title{
Comparing global and regional maps of intactness in the boreal region of North America: Implications for conservation planning in one of the world's remaining wilderness areas
}

October 26, 2020

Pierre Vernier ${ }^{1}$, Shawn Leroux ${ }^{2}$, Steve Cumming ${ }^{3}$, Kim Lisgo ${ }^{1}$, Alberto Suarez Esteban ${ }^{1}$, Meg Krawchuck ${ }^{4}$, Fiona Schmiegelow ${ }^{1,5}$

${ }^{1}$ Department of Renewable Resources, University of Alberta, Edmonton, Alberta, Canada

2 Department of Biology, Memorial University of Newfoundland, St John's, Newfoundland, Canada

${ }^{3}$ Département des sciences du bois et de la forêt, Université Laval, Québec, Québec, Canada

${ }^{4}$ Department of Forest Ecosystems and Society, Oregon State University, Corvallis, Oregon, USA

${ }^{5}$ Yukon Research Centre, Yukon University, Whitehorse, Yukon, Canada

* Corresponding author

E-mail: pierre.vernier@gmail.com

I These Authors contributed equally to this work

\& These authors also contributed equally to this work 


\begin{abstract}
Though North America's boreal forest contains some of the largest remaining intact and wild ecosystems in the world, human activities are systematically reducing its extent. Consequently, forest intactness and human influence maps are increasingly used for monitoring and conservation planning in the boreal region. We compare eight forest intactness and human impact maps to provide a multimodel assessment of intactness in the boreal region. All maps are global in extent except for Global Forest Watch Canada's Human Access (2000) and Intact Forest Landscapes $(2000,2013)$ maps, although some global maps are restricted to areas that were at least $20 \%$ treed. As a function of each map's spatial coverage in North America, the area identified as intact ranged from 55\% to $79 \%$ in Canada and from $32 \%$ to $96 \%$ in Alaska. Likewise, the similarity between pairs of datasets in the Canadian boreal ranged from 0.58 to 0.86 on a scale of $0-1$. In total, $45 \%$ of the region was identified as intact by the seven most recent datasets. There was also variation in the ability of the datasets to account for anthropogenic disturbances that are increasingly common in the boreal region, such as those associated with resource extraction. In comparison to a recently developed high resolution regional disturbance dataset, the four human influence datasets (Human Footprint, Global Human Modification, Large Intact Areas, and Anthropogenic Biomes), in particular, omitted 59-85\% of all linear disturbances and 54-89\% of all polygonal disturbances. In contrast, the global IFL, Canadian IFL, and Human Access maps omitted $2-7 \%$ of linear disturbances and $0.1-5 \%$ of polygonal disturbances. Several differences in map characteristics, including input datasets and methods used to develop the maps may help explain these differences. Ultimately, the decision on which dataset to use will depend on the objectives of each specific conservation planning project, but we recommend using datasets that 1 ) incorporate regional anthropogenic activities, 2) are updated regularly, 3) provide detailed information of the methods and input data used, and 4) can be replicated and adapted for local use. This is especially important in landscapes that are undergoing rapid change due to development, such as the boreal forest of North
\end{abstract} America. 


\section{Introduction}

North America's boreal forest contains some of the largest remaining intact ecosystems in the world (Potapov et al. 2017, Watson et al. 2018). However, the rapid expansion of industrial activities such as forestry, mining, and oil and gas exploration into increasingly accessible landscapes is systematically reducing its extent (Bradshaw et al. 2009, CEC 2010, Schindler and Lee 2010, Brandt et al. 2013, Venier et al. 2014). Large intact areas support biodiversity, ecological and evolutionary processes including wildlife migrations and natural disturbances, and ecosystem services such as carbon capture and sequestration (Mittermeier et al. 2003, Leroux et al. 2010, Watson et al. 2016). They also play an important role in climate change mitigation (Price et al. 2013, Melillo et al. 2016, Carroll and Noss 2020) and can serve as ecological baselines to guide sustainable land management practices (Arcese and Sinclair 2016). Despite their importance and recent calls for the expansion of protected areas in intact or wilderness regions (Betts et al. 2017, Dinerstein et al. 2017, Tilman et al. 2017), the global erosion of wilderness areas has exceeded their rate of protection (Watson et al. 2016). To identify and conserve additional wilderness and intact areas, reliable and up-to-date spatial information is required. This has led to the production of several global and regional datasets that attempt to map anthropogenic disturbances or their complement, areas with little or no evidence of human activities (McCloskey and Spalding 1989, Bryant 1997, Sanderson et al. 2002, Potapov et al. 2008b, Hansen et al. 2013). The maps vary in methodology, spatial and temporal characteristics, and most importantly, the area estimated to be intact in the boreal region. Consequently, a comparison of map products would assist conservation planners and researchers with the selection of the most appropriate product(s) for their purposes.

The boreal region of North America covers 6.3 million $\mathrm{km}^{2}$, of which $88 \%$ is in Canada and $12 \%$ is in Alaska (Brandt et al. 2013). In Canada, 11.4\% of the region is currently under some form of protection (CPCAD 2019), and both globally and in Canada, there is increasing recognition of the need to expand protected areas while opportunities remain. In response, the United Nations Convention on Biological Diversity developed a set of goals ("Aichi Targets") for protecting biodiversity which includes a target of 17\% of terrestrial areas conserved by 2020 (Butchart et al. 2016), with a proposed increase to 30\% by 2030 (Dinerstein et al. 2019). At the regional level, the Governments of Ontario and Quebec have committed to setting aside $50 \%$ of the boreal region of each province in various levels of protection in anticipation of future resource development (Government of Quebec (Minister of Natural Resources and Wildlife) 2009, Hansen et al. 2010, OMNR 2013). Beyond their use in conservation planning, intact 
forests are being considered as a policy instrument in forest conservation and management and have recently been integrated into the certification standards of the Forest Stewardship Council (FSC 2015). The forests and peatlands of the boreal region also are important carbon sinks and the maintenance of intact forest landscapes may be part of a natural solution to carbon sequestration and $\mathrm{CO}_{2}$ reduction (Griscom et al. 2017). Consequently, intact areas have an important role to play in protected area design and as control areas against which the impacts of human activities on biodiversity can be compared within an adaptive management framework (Lindenmayer et al. 2006, Watson et al. 2009).

In the boreal region where forests dominate the landscape, wilderness or intact areas have much in common with the concept of the Intact Forest Landscape (IFL), defined as "a seamless mosaic of forest and naturally treeless ecosystems within the zone of current forest extent, which exhibit no remotely detected signs of human activity or habitat fragmentation and is large enough to maintain all native biological diversity, including viable populations of wide-ranging species" (Potapov et al. 2008). Depending on the IFL dataset, intact areas must be a minimum of 1,000 ha to 50,000 ha (Potapov et al. 2008, Lee et al. 2010). An area becomes non-intact through the accumulation of human impacts, often related to resource extraction activities such as logging, mining, oil and gas development, and their associated roads. In this context, intactness is considered to be a structural descriptor of landscapes that reflects the absence of anthropogenic disturbances as measured from thematic (e.g., roads) and remote sensing data.

Several global and regional initiatives have attempted to map the overall condition of the world's ecosystems in the past 30 years (Table 1). The initiatives can be divided into two broad groups based on their objective: intactness mapping and human influence mapping. The intactness mapping approach attempts to map remaining areas with little or no human activities by removing anthropogenic disturbances that are detectable using satellite imagery and other input data, and sometimes applying a zone of influence buffer. Resulting areas are considered free from significant human pressures. In contrast, the human influence mapping approach combines multiple disturbance layers into an overall map showing areas of low to high disturbances. Areas with the least amount of disturbance can then be reclassified to identify relatively intact areas. Among the intactness mapping approaches, the World Wilderness Areas map was one of the first global initiatives (McCloskey and Spalding 1989). To qualify, areas had to be $\geq 4,000 \mathrm{~km}^{2}$ after eliminating all areas within $6 \mathrm{~km}$ of human infrastructures e.g., roads and settlements. Subsequently, the Frontier Forests initiative, produced by the World Resources 
Institute, also attempted to map the world's remaining large intact natural forests (Bryant 1997). No explicit minimum size was specified and, similar to wilderness areas, human disturbances due to traditional activities were considered acceptable. The concept, however, has been questioned for its utility for identifying high priority conservation areas because of the methods and criteria used to define intact forests (Innes and Er 2002). More recently, Global Forest Watch (GFW) built upon the concept of the Frontier Forest to develop a global map of intact forest landscapes (IFLs), delineated using specific criteria related to minimum size, patch width, and corridor width (Potapov et al. 2008, 2017). The global IFL maps were produced for the years 2000, 2013 and 2016. The approach has also been applied at a regional scale in Canada for the years 2000 and 2013 by GFW Canada (Lee et al. 2010, Smith and Cheng 2016), although it diverges from the global definition with respect to some of the criteria, for example the treatment of wildfires (Lee 2009).

Among the human influence mapping approaches, the best known is the Human Footprint (HFP), which provides a standardized measure of cumulative human pressures on the environment based on the extent of built environments (e.g., urban areas), crop land, pasture land, human population density, night-time lights, railways, roads and navigable waterways (Sanderson et al. 2002). The HFP has been updated several times while adhering to consistent methods, with the most recent dataset current to 2013 (Venter et al. 2016, Williams et al. 2020). All versions of the HFP can be reclassified to identify areas with little or no disturbances. Another well-known dataset is the Anthropogenic Biomes (Anthromes) map (Ellis and Ramankutty 2008) that classifies the terrestrial biosphere into 19 categories based on human interactions with ecosystems, including agriculture, urbanization, forestry and other land uses. It has also been updated for multiple years, with the most recent version current to 2015 (Ellis et al. 2020). For all versions, the most relevant categories for mapping intact areas are the wildland categories (wild forest, sparse trees and barren). Two additional recent datasets, the (Very) Low Impact Areas map (Jacobson et al. 2019) and the Global Human Modification map (Kennedy et al. 2019) also provide a cumulative measure of human modification of terrestrial lands across the globe at a 1-km² resolution for the years 2015 and 2016, respectively. Both approaches are similar to the HFP approach but differ in the number and types of anthropogenic stressor datasets, as well as the methods used to calculate human influence (Riggio et al. 2020). At a regional scale, GFW Canada also developed the Human Access dataset for 2010 as an intermediary step to creating the Canada IFL 2013 map (Lee and Cheng 2014). The dataset maps recent linear and areal disturbances related to resource extraction but, 
unlike the IFL datasets, does not use a minimum size criterion, although buffers are applied around disturbances (Table 1).

The availability of an increasing number of intactness and human influence maps may lead to confusion about the suitability of the various products for conservation planning in the boreal region, especially since many of the datasets are global in extent. To identify the most suitable dataset, it would help to not only understand the differences in characteristics and assumptions of each map, but also how well their predictions agree with each other and against independent and higher-resolution regional data. A recent study comparing the four human influence maps at the global scale found that despite differences in methods and data, the datasets estimated similar percentages of low and very low human influence areas (Riggio et al. 2020). In the current study, we evaluated both intactness and human influence datasets (with the exception the World Wilderness Areas), focusing on the boreal region of Canada. Our overall objective was to compare and evaluate existing map products that can be used to measure intactness. Our specific objectives were to:

1. To compare intactness estimates across the boreal region of Canada and Alaska;

2. To quantify inter-map agreement and identify areas of common agreement; and

3. To evaluate the strengths and limitations of the maps to accurately identify anthropogenic disturbances common in the boreal region: oil and gas exploration, logging, roads, and mining.

We also provide two case studies in the supporting information: the first, on the effectiveness of intactness and human influence maps at identifying disturbances related to placer mining in westcentral Yukon, and the second, on the sensitivity of intactness estimates to buffer size and minimum patch size in northern Alberta.

\section{Methods}

Our overall study area comprises the spatial extent of the boreal and boreal alpine regions (i.e., the boreal region) of North America (Brandt 2009). However, most of our analysis is focused on a large subset of the Canadian boreal region (Figure 1, black outline), representing the intersection of the intactness and human influence maps evaluated. In total, we acquired eight freely available national and global maps that at a minimum, covered a large portion of the study region. All maps are global in extent except for those produced by GFW Canada which are restricted to Canada's boreal and temperate 
forests. Four of the maps were produced for multiple periods for a total of 17 datasets (maps $x$ years). Table 1 summarizes the general characteristics of each dataset including geographic extent, format, resolution, measurement scale, and source of input data. The table also provides information on mapping methods, including geographic extent, resolution, minimum size of intact areas, disturbance types, and buffering of disturbances.

\section{Intactness estimates and spatial agreement}

The eight intactness and human influence map products varied in geographic coverage, mapped values, scale, coordinate system, and GIS file format. To enable comparisons of intactness estimates across maps across the boreal region, we converted all maps to an Albers Equal Area projection, clipped them to the boreal region of Canada and Alaska, and vectorized the raster datasets. We then reclassified the maps, where necessary, to binary "intactness" maps, with 1 indicating intact areas (i.e., little or no human influence) and 0 identifying non-intact areas. For the human footprint maps (HFP2000-13) and very low impact areas map (VLIA2015), all areas with little or no human influence (pixel values=0) were assigned a value of 1 while remaining areas were assigned a value of 0 . For the global human modification map (GHM2016), we followed Riggio et al. (2002) and assigned pixels with values ranging from 0-0.01 a value of 1. For the HA2010 map, we eliminated all disturbance polygons from the boreal study region and assigned a value of 1 to the resultant areas. For the frontier forest map (FF), all polygons were assigned a value of 1 irrespective of their threat level. For the anthropogenic biome maps (AB2000-15), we assigned a value of 1 to the wildland categories i.e., wild forest, sparse trees and barren. Following map reclassifications, we calculated, for each map, the proportional area of the boreal region identified as intact. Since not all datasets covered the entire boreal region, the intact area identified by each dataset was divided by the total area of the map's coverage within the boreal rather than by the area of the boreal. For Canada, we estimated intactness using all datasets. For Alaska, we used all datasets except for the GFW Canada datasets.

To evaluate the spatial agreement of datasets, we rasterized or resampled all maps to a $1000-\mathrm{m}$ resolution, the most common resolution amongst the datasets evaluated. We restricted the spatial extent of the analysis to the area of intersection of all datasets. For the Canada IFL, Global IFL and HFP maps, we used the most recent maps. Frontier Forests was excluded because of its age and low original resolution. We quantified the area of spatial agreement (i.e., pairwise similarities) between the maps 
using Jaccard's similarity coefficient (Fewster and Buckland 2001). The Jaccard coefficient measures the similarity between datasets, and is defined as the area of intersection of two datasets divided by the area of union. Values for the coefficient range from 0 (complete dissimilarity) to 1 (complete similarity). All analyses were conducted using R 4.0.2 (Team n.d.) and the sf (Pedzema 2018) and raster (Hijmans 2016) packages.

\section{Accuracy assessment}

One of the main objectives of this study was to assess how well intactness and human influence datasets account for anthropogenic disturbances that are increasingly common in the boreal region, namely those associated with energy extraction, forestry, and mining. To do this, we used the boreal ecosystem anthropogenic disturbance (BEAD) dataset updated to 2015, a high-resolution dataset that was created specifically to identify disturbances in and around 51 boreal caribou ranges (Figure 1 hatched area; Pasher et al. 2013). Two broad types of disturbances were mapped within each range: 1) linear disturbances such as roads, seismic cutlines, and pipelines and 2) polygonal disturbances such as forest cutblocks, agricultural areas, and mining quarries. The dataset consists of both buffered and unbuffered linear and polygonal disturbances, covering 4.4 million $\mathrm{km}^{2}$ of the boreal encompassing 51 caribou ranges, and was produced using both 30- and 15-m resolution Landsat 8 data. In our analysis, we used the unbuffered dataset to evaluate the seven most recent datasets: HA2010, Canada IFL2013, Global IFL2016, HFP2013, AB2015, VLIA2015, and GHM2016. For each caribou range, we estimated of the proportion of linear and polygonal disturbance types omitted by each intactness and human influence map. These estimates are conservative because no buffer was applied to the disturbances.

\section{Results}

Intactness estimates and spatial agreement

All maps except for the Global IFL maps covered at least 98\% of the boreal region of Canada as defined by Brandt (Brandt 2009) (Table 2, Supp Info S1). The three Global IFL maps covered $86 \%$ of the region. The total area identified as intact within the spatial extent of each map, ranged from $55-59 \%$ for the three global IFL maps (GIFL2000-16) to 89\% for the four Anthromes maps (AB2000-15). The amount identified by the GHM2016, HA2010, and the four Human Footprint maps were very similar, ranging 
from $81-84 \%$. In contrast, the FF1996 map was relatively low, with only $60 \%$ of the boreal identified as intact. The remaining datasets range between 71-76\% for VLIA2015 and Canada IFL datasets (CIFL200013), respectively. Among multi-temporal datasets, the CIFL2013 map identified 3.6\% less intact forest than the CIFL2000 map while the GIFL2016 map identified 3.4\% less intact area than the GIFL2000 map. In contrast, the reduction in intact area between the newest and oldest HFP and AB maps was only 0.3 and $0.1 \%$, respectively. In Alaska, the area identified as intact varied more widely than in Canada, ranging from 32\% for the FF1996 map to 96\% for the GHM2016 map (Table 2, Supp Info S1). The global IFL maps identified 19-21\% more intact area in Alaska than in Canada with a 6\% reduction between the oldest and newest maps. The Anthromes and Human Footprint maps had similar proportional values to Canada with little change over time.

Spatial agreement, as measured by Jaccard's similarity coefficient between intactness maps, ranged from a low of 0.58 between the GIFL2016 and VLIA2015 maps to a high of 0.86 between the AB2015 and GHM2016 maps (Table 3). Compared to the other maps, the similarity between the GIFL2016 map and all other maps except for CIFL2013 was 0.67 or less. With CIFL2013, it was 0.77 . Most other paired comparison ranged between 0.70 and 0.85 , indicating a relatively strong level of similarity. The intersection of the seven intactness maps revealed that $45 \%$ of the study region was identified as intact by all seven maps and an additional $18 \%$ by at least six of the maps (Figure 2). Only $3 \%$ of the study region was identified as not intact by all maps.

\section{Accuracy assessment}

The area identified as intact within the 51 caribou ranges by the seven intactness $(N=3)$ and human influence ( $N=4$ ) datasets ranged from 45\% for the GIFL2016 map to 93\% for the AB2015 map (Table 4). There were 31\% more linear disturbances identified with the $15-\mathrm{m}$ data than with the 30-m data. Most of the differences were due to seismic lines ( $41 \%$ more) and roads ( $22 \%$ more). In contrast, there was only $0.2 \%$ more polygonal disturbances identified with the $15-\mathrm{m}$ data than with the $30-\mathrm{m}$ data. Overall, the four human influence datasets (HFP2013, AB2015, VLIA2015, GHM2016), omitted 59-85\% of all linear disturbances and $54-89 \%$ of all polygonal disturbances. In contrast, the intactness datasets (GIFL2016, CIFL2013, and HA2010) omitted between 2-7\% of linear disturbances and 0.1-5\% of polygonal disturbances. 
The most common linear anthropogenic disturbances in the study area were seismic cutlines, roads, pipelines and powerlines. Railways, airstrips, and dams also occurred, but to a much lesser extent. In general, the four human influence datasets omitted all linear disturbance types much more than the intactness datasets, $49-74 \%$ on average compared to 0-8\% for the intactness datasets. The VLIA2015 map omitted all disturbance types more often than any other map. The HFP2013 map was the only human influence dataset that had some omission rates below $20 \%$, specifically for railways and dams. Among the human influence datasets, omission of seismic lines ranged from $62 \%$ by the $A B 2015$ map to $89 \%$ by the VLIA2015 map. This compares to $2-7 \%$ for the intactness datasets. Roads, pipelines, and powerlines were also omitted $37-81 \%$ of the time by the human influence datasets compared to $0-8 \%$ for the intactness datasets. Among the intactness group, the CIFL2013 and GIFL2016 performed best, omitting only $2-4 \%$ of seismic lines and roads, respectively. Only dams were omitted more than $10 \%$ of the time, by the HA2010 and CIFL2013 maps. The GIFL2016 map never exceed an omission rate of 5\% while the HA2010 consistently omitted more linear disturbances than CIFL2013 and GIFL2016.

By far, the most common and widely distributed anthropogenic polygonal disturbances in the study area were forest cutblocks followed by agriculture, settlements, and mines. Well sites and other oil and gas infrastructure also occurred to a much lesser extent. In general, and as with linear disturbances, the four human influence datasets omitted all polygonal disturbance types more than the intactness datasets, $10-73 \%$ on average compared to $0.2-2 \%$ for the intactness datasets. In particular, cutblocks were omitted $57-91 \%$ of the time by the human influence datasets. This compares to $0.1-5 \%$ for the intactness datasets. Mines and well sites were also more often omitted by the human influence maps. Among the human influence datasets, the HFP2013 map had the lowest omission rate for all polygonal disturbance types except for well sites. Both CIFL2013 and GIFL2013 never exceeded a 1\% omission rate for any polygonal disturbance type. Similar to the linear disturbances, the HA2010 map had higher omission rates than the two IFL maps, although it never exceeded $5 \%$.

The use of higher resolution test data was most noticeable with linear disturbances, with $68 \%$ and $28 \%$ seismic lines and roads identified, respectively. This had much larger impact on the intactness datasets, roughly doubling the omission rates of roads for HA2010, CIFL2013 and GIFL2013 and of seismic lines for HA2010 and CIFL2013. Even with these increases, however, the overall omission rates for all linear disturbances for CIFL2013 and GIFL2013 was less than 6.5\%. In contrast, the omission rates for the 
human influence datasets did not change much but remained much higher than for the intactness datasets.

Case studies

The supporting information includes results from two case studies. The first case study evaluates the effectiveness of the intactness and human influence maps at identifying disturbances related to placer mining in west-central Yukon (S2_case_study_1.html). Among the 7 datasets we analysed, the GIFL2016 map omitted the least amount of both linear and polygonal anthropogenic disturbances $(0.0 \%$ and $1.9 \%$, respectively; Table 1 ). However, it only identified only $12.3 \%$ of the study region as being intact, far less than the CIFL2013 and HFP2013 maps which identified 49\% and 55\% of the area as intact, respectively. Three of the datasets, VLIA2015, GHM2016 and AB2015, identified 92-96\% of the area as being intact and, consequently had very high rates of omission, ranging from 66-95\% for linear disturbances and 88 98\% for polygonal disturbances. The other two datasets, CIFL2013 and HA2010 omitted a moderate amount of both polygonal ( $12 \%$ and $22 \%$, respectively) and linear ( $21 \%$ and $38 \%$, respectively) disturbances. The second case study consists of a simple two factor analysis conducted in northern Alberta to illustrate the sensitivity of intactness estimates to buffer size and minimum intact patch size (S3_case_study_2.html). The results indicate that the area estimated to be intact varies from 44-98\% depending of buffer size and minimum intact patch area, with buffer size having a larger influence than minimum patch size (Table S3.2, Figure S3.2).

\section{Discussion}

The boreal region of North America is experiencing rapid industrial development (Brandt et al. 2013, Venier et al. 2014, White et al. 2017). Consequently, there is a need for reliable and up-to-date information on changes in ecosystem conditions. To that end, we compared eight global and regional maps depicting intactness or cumulative human influence on ecosystems in the boreal region. Our results revealed large differences in the area estimated to be intact or relatively free from human influence. In Canada, estimates ranged from $55-89 \%$ while in Alaska they ranged even more, from 32$96 \%$. Likewise, the similarity between pairs of datasets in the Canadian boreal ranged from 0.58 to 0.86 on a scale of $0-1$. In total, $45 \%$ of the region was identified as intact by the seven most recent datasets. This variation was also evident in the ability of the datasets to account for anthropogenic disturbances 
that are increasingly common in the boreal region, especially those associated with resource extraction. The four human influence datasets (Human Footprint, Global Human Modification, Large Intact Areas, and Anthromes), in particular, omitted $59-85 \%$ of all linear disturbances and $54-89 \%$ of all polygonal disturbances. In contrast, the Global IFL, Canada IFL, and Human Access maps omitted 2-7\% of linear disturbances and $0.1-5 \%$ of polygonal disturbances. Several differences in map characteristics, including input datasets and methods used to develop the maps may help explain those differences.

Input datasets appear to play an important role in the observed variation in intactness estimates, spatial agreement between maps, and the ability to detect both linear and polygonal anthropogenic disturbances. Among the datasets evaluated, the four human influence maps relied mostly on combining existing thematic maps that each represented one stressor into a cumulative disturbance map. The primary stressors used were mostly related to settlement, agriculture, population density and transportation, with little information on resource extraction activities. Exceptions included the use of a forest cover change map (Hansen et al. 2013) by the Low Impact Areas dataset and mining and oil wells by the Global Human Modification dataset. Even so, this did not make a big difference in the omission rates of those disturbances. Moreover, the majority of input datasets were raster maps with a resolution that was generally $\geq 1-\mathrm{km}^{2}$, which also contributed to the omission of finer-scale anthropogenic changes and disturbances. In contrast, the Human Access and IFL maps mostly relied on processing high resolution satellite imagery (i.e., 30-m) along with some thematic maps to identify disturbances. This resulted in far fewer omissions of anthropogenic disturbances related to resource development such as forest cutblocks, pipelines, seismic lines and roads. However, the use of even finer resolution test data (i.e., 15-m) revealed increased omission rates, especially for seismic cutlines and roads, whose width make them particularly challenging to detect without imagery of an appropriate resolution. In the case of seismic lines, there has also been a reduction in their width over time which would also contribute to newer lines being undetected by satellite imagery (Lee and Boutin 2006, van Rensen et al. 2015).

The age and temporal resolution (i.e., how often they are updated) of datasets also has important implications for their suitability for conservation planning, especially in areas of the boreal that are rapidly changing, including the boreal plains of western Canada, and southern parts of the boreal shield in Ontario and Quebec (Government of Quebec 2009, OMNR 2013). Older datasets that were only produced once, such as Frontier Forests, may be useful from a historical perspective but would be a 
poor choice for conservation planning. More recent datasets, such as the Human Access and Canada IFL maps, have now been discontinued leaving only the Global IFL map as a true intactness dataset. The increasingly rapid pace of industrial development means that even recently produced intactness maps are quickly out-of-date, suggesting the importance of updating maps on a regular basis, ideally annually. Three datasets, Human Footprint, Anthromes and Global IFL, stood out for having at least three updated products between 2000-2016, allowing for monitoring and change detection based on consistent and replicable methods. Newer datasets, such as the Global Human Modification and Low Impact Areas, have only one temporal product but may provide a complementary approach to the Human Footprint for assessing ecosystem conditions at a global scale. In fact, despite their differences, those three datasets along with the Anthromes datasets provided similar estimates of the amount of remaining terrestrial ecosystems with very low human influence (Riggio et al. 2020).

Methodological differences among maps were mostly related to study area delineation, minimum intact patch size, and the use of exclusion buffers around linear and polygonal anthropogenic disturbances. For example, some of the discrepancies between the Frontier Forests and Canada IFL maps are due to the delineation of the Frontier Forests forest zone, which excluded northern, less densely forested portions of the Canadian boreal. Similarly, the Global IFL maps used a satellite-based global tree cover map to define their study area, resulting in some parts of the boreal region being excluded because tree canopy was $<20 \%$. The use of a minimum intact patch size also contributed to discrepancies among maps, with four of the maps specifying a minimum size. The Global IFL maps, for example, considered that an intact forest should have a minimum size of 50,000 ha (Potapov et al. 2017). In contrast, the Canada IFL maps used a minimum threshold of 5,000 ha for boreal ecozones and 1,000 ha for temperate ecozones (Smith and Cheng 2016); the latter only occurred along the southern edge of the boreal region. Consequently, a greater total area of intact forests was identified by the Canada IFL maps. Other maps, such as the Human Access map, did not have a minimum area requirement and consequently identified an even greater amount of intact area. This resulted in higher omission rates for linear and polygonal disturbances in comparison to the IFL maps, in particular in areas identified as being intact and smaller than the minimum patch size used by the other maps.

The applied widths of human influence zones (or buffers) also contributed to differences in the extent of mapped intact areas. For example, the Human Footprint maps considered up to 15-km wide zones of influence around features such as roads, major rivers and coastlines, since they are often used as 
transportation corridors or have high population densities. While there is plenty of evidence that human activities can have impacts beyond the point source (e.g., wolf avoidance of areas with human activities (Shepherd and Whittington 2006); impacts of riparian forest harvesting on streams (Richardson and Béraud 2014)), the use of thresholds eliminated many areas considered intact by the Human Access and IFL maps. This may be justified in some coastal zones of Europe and more populated regions of North America, but it is not as well supported in remote areas of the northern boreal forest, where population density is negligible. Our second case study provided a simple illustration of the sensitivity of IFL estimates to the size of exclusion buffers and the minimum intact patch size on intactness estimates (Supp Info). In particular, the use of buffer exclusion zones by themselves resulted in a much greater reduction in intact areas than the use of a minimum intact patch size criteria on its own. The use of simple buffers around disturbances limits the users' ability to use a more flexible and nuanced approach to allocating degrees of intactness within areas that have not been disturbed but are close to a disturbance. For example, when identifying reserves for species that have strong avoidance of humanimpacted areas such as caribou (Environment Canada 2008), these buffers may be appropriate, and would not represent an underestimation of intact areas. However, when conservation efforts focus on less sensitive species, these buffers may be too conservative and underestimate the amount of suitable habitat. To be most flexible, intactness mapping projects could avoid using buffers or at least provide underlying unbuffered data.

Overall, and as with input data, the datasets we evaluated can be broadly divided into two groups based on similarities in their methodology, with the IFL and Human Access maps belonging to one group and the four human influence maps belonging to the other. However, even within groups, minor differences in methods resulted in relatively important differences in the areas identified as intact. For example, the Global IFL maps considered all wildfires occurring in proximity to infrastructure (e.g., settlements) as non-intact, resulting in less intact area identified in comparison to the Canada IFL maps (Lee 2009). Fires play crucial roles in the dynamics of Canadian boreal forests, where most of the area burned is due to lightning-caused fires (Price et al. 2013). This alone would account for an under-estimation of 400,000 $\mathrm{km}^{2}$ of intact boreal and temperate forests in Canada by the Global IFL maps (Lee 2009). Another source of disagreement was due to the treatment of rivers affected by hydroelectric power generation, which were excluded using a 1-km buffer by the Global IFL maps but not by the Canada IFL and Human Access maps. 
Global maps such as the Anthropogenic Biomes, Global Human Modification, Low Impact Areas and Human Footprint maps may be appropriate for broad-scale conservation assessments where finer resolution data are not available. For example, this approach was used to identify and prioritize global wilderness areas (Mittermeier et al. 2003), identify remaining intact areas globally and within biomes (Riggio et al. 2020), and analyse the connectivity of protected areas via intact land (Ward et al. 2020). However, obtaining more detailed and up-to-date regional maps of intactness or disturbances should be a priority for any systematic conservation planning exercise, in the boreal or elsewhere. Increasingly, researchers are using freely available satellite imagery to produce time series of high resolution land cover maps, including maps that track changes in forest disturbances (e.g., White et al. 2017). In addition, there exists several examples of regional intactness and human influence maps in North America and other parts of the world. For example, the Human Footprint approach has been applied at regional scales in the United States and Canada (Woolmer et al. 2008, Leu et al. 2008). Other recent related initiatives have aimed to characterize landscape patterns, forest fragmentation, and forest change at regional (Raiter et al. 2017), national (Wulder et al. 2008, Pasher et al. 2013, Guindon et al. 2014, White et al. 2017) and global scales (Hansen et al. 2013). Regional datasets also afford greater sophistication by integrating information on context, connectivity, habitat, and species (e.g., Plumptre et al. 2019, Grantham et al. 2020, Mokany et al. 2020). As an indication of the importance of considering intact areas in conservation planning, a major international conference on "Intact Forests in the 21st Century" recently took place in Oxford in $2018^{1}$ to discuss regional and global approaches.

The development of intactness and human influence datasets has also led to some critiques on the utility of the concept of intactness (e.g., Innes and Er 2002, Bernier et al. 2017, Venier et al. 2018) and debates amongst mapping methods (e.g., Kennedy et al. 2020, Venter et al. 2020, Riggio et al. 2020). Two recent papers, with relevance to the boreal context, argue for a more sophisticated approach to the assessment of the loss of ecological value from forests. Bernier et al. (2017) reviewed the concept of "primary forest" as a metric of forest environmental quality, and its use by the Food and Agriculture Organization (FAO) for reporting country-level statistics. Of particular concern is the lack of a consistent operational definition resulting in substantial differences in the way primary forest areas are defined and measured within each country. They note that more recent approaches, such as IFLs, provide more consistency by using satellite imagery but do not consider regional differences in ecosystem processes

\footnotetext{
${ }^{1}$ https://www.eci.ox.ac.uk/if21/
} 
that can result in large differences in areas identified as intact. Venier et al. (2018) distinguished between conceptual and operational definitions of an IFL and provides a historical review of the intact forest landscape concept and intactness mapping, both globally and regionally. Both papers point out limitations in the criteria used to map intact areas and argue for a more sophisticated approach, one that considers intactness as a gradient rather than a binary condition and where the minimum patch size is not standardized but guided by regional ecological conditions and processes. Specifically, the standard operational definition of a Global IFL sets a minimum intact patch size of 50,000 ha, which is arbitrary and disconnected from regional ecosystem processes which may require a smaller or larger minimum size. For example, the minimum intact patch size may be too small for wide ranging species such as caribou and wolverine and for ecosystem processes such as wildfires which can exceed 1,000,000 ha in the boreal region. Ideally, the minimum size that an intact patch needs for conservation planning should be related to habitat requirements for focal species and ecological processes (Haddad et al. 2015).

Our analysis has some limitations. For example, we only reviewed existing datasets that were freely available and covered the boreal region of Canada at a minimum, but we did not consider regional datasets. An evaluation of regional intactness and human influence datasets would be useful since many conservation decisions are made at those scales. In addition, our analysis represents a snapshot in time as i) datasets are continually being produced, revised or updated and ii) anthropogenic disturbances are happening every day in the boreal region. Our evaluation of both intactness and human influence datasets also required that some datasets be reclassified to binary maps identifying only areas with minimum human impacts. However, not all datasets had a clear "no impact" class, and consequently, we reclassified some of the maps to create an analogous class showing areas with little or no influence. For one dataset, the Global Human Modification map, we used values ranging from 0-0.01 to be consistent with methods used by Riggio et al. (2020).

The boreal region of North America is currently undergoing rapid industrial development, and there is an urgent need to quantify changes in ecosystem conditions and to identify new protected areas. Several datasets have been developed over the last two decades that can be used to assist in monitoring, conservation planning, and adaptive management. The datasets can be broadly grouped into i) those that combine existing stressor datasets to create a cumulative human influence map and ii) those that process satellite imagery to identify and map disturbances. For all linear and polygon anthropogenic disturbance types, the former group was shown to be far less effective than the latter at 
incorporating anthropogenic disturbances related to resource development in the boreal. However, even among the latter group, the use of buffers and minimum patch sizes limit the flexibility of those products to enable more sophisticated conservation planning. Encouragingly, the increasing concern due to climate and land use change is leading to the continued refinement or revision of existing datasets over time and the development of new products using more sophisticated approaches and finer resolution input data. Moreover, many datasets are being provided freely and some with accompanying algorithms and code used to develop them (e.g., the Human Footprint), allowing approaches to be replicated or adapted for regional use. In addition, many Canadian provinces are now making available historical and modern datasets related to resource management and development. Ultimately, the decision on which dataset to use will depend on the objectives of the conservation planning initiative and the availability of the most recent high quality datasets available in the planning region. Our goal was to contribute to the review and assessment of some widely available datasets and provide some guidance for their use in the boreal context.

\section{Supporting information}

The following supplementary tables and maps are available on GitHub (https://github.com/prvernier/intactness):

- S1_datasets.md. Description of intactness and human influence datasets within the boreal region of Canada and Alaska.

- S2_case_study_1.html. Effectiveness of intactness and human influence maps at identifying disturbances related to placer mining in west-central Yukon.

- S3_case_study_2.html. Sensitivity of intactness estimates to buffer size and minimum patch size.

\section{References}

Arcese, P., and A. R. E. Sinclair. 2016. The role of protected areas as ecological baselines. The Journal of Wildlife Management 90:275-282. 
Betts, M. G., C. Wolf, W. J. Ripple, B. Phalan, K. A. Millers, A. Duarte, S. H. M. Butchart, and T. Levi. 2017. Global forest loss disproportionately erodes biodiversity in intact landscapes. Nature 547:441444.

Bradshaw, C. J. A., I. G. Warkentin, and N. S. Sodhi. 2009. Urgent preservation of boreal carbon stocks and biodiversity. Trends in Ecology and Evolution 24:541-548.

Brandt, J. P. 2009. The extent of the North American boreal zone. Environmental Reviews 17:101-161.

Brandt, J. P., M. D. Flannigan, D. G. Maynard, and I. D. Thompson. 2013. An introduction to Canada's boreal zone : ecosystem processes, health, sustainability, and environmental issues. Environmental Reviews 226:207-226.

Bryant. 1997. The Last Frontier Forests. World Resources Institute.

Butchart, S. H. M., M. Di Marco, and J. E. M. Watson. 2016. Formulating Smart Commitments on Biodiversity: Lessons from the Aichi Targets: Lessons from the Aichi Targets. Conservation Letters 9:457-468.

Carroll, C., and R. F. Noss. 2020. Rewilding in the face of climate change. Conservation Biology:cobi.13531.

CEC. 2010. Terrestrial Protected Areas of North America. http://www.cec.org/.

Dinerstein, E., D. Olson, A. Joshi, C. Vynne, N. D. Burgess, E. Wikramanayake, N. Hahn, S. Palminteri, P. Hedao, R. Noss, M. Hansen, H. Locke, E. C. Ellis, B. Jones, C. V. Barber, R. Hayes, C. Kormos, V. Martin, E. Crist, W. Sechrest, L. Price, J. E. M. Baillie, D. Weeden, K. Suckling, C. Davis, N. Sizer, R. Moore, D. Thau, T. Birch, P. Potapov, S. Turubanova, A. Tyukavina, N. De Souza, L. Pintea, J. C. Brito, O. A. Llewellyn, A. G. Miller, A. Patzelt, S. A. Ghazanfar, J. Timberlake, H. Klöser, Y. Shennan-Farpón, R. Kindt, J. P. B. Lillesø, P. Van Breugel, L. Graudal, M. Voge, K. F. Al-Shammari, and M. Saleem. 2017. An Ecoregion-Based Approach to Protecting Half the Terrestrial Realm. BioScience 67:534-545. 
Dinerstein, E., C. Vynne, E. Sala, A. R. Joshi, S. Fernando, T. E. Lovejoy, J. Mayorga, D. Olson, G. P. Asner, J. E. M. Baillie, N. D. Burgess, K. Burkart, R. F. Noss, Y. P. Zhang, A. Baccini, T. Birch, N. Hahn, L. N. Joppa, and E. Wikramanayake. 2019. A Global Deal For Nature: Guiding principles, milestones, and targets. Science Advances 5:eaaw2869.

Ellis, E. C., A. H. W. Beusen, and K. K. Goldewijk. 2020. Anthropogenic Biomes: 10,000 BCE to 2015 CE. Land 9:129.

Ellis, E. C., and N. Ramankutty. 2008. Putting people in the map: anthropogenic biomes of the world. Frontiers in Ecology and the Environment 6:439-447.

Fewster, R. M., and S. T. Buckland. 2001. Similarity Indices for Spatia I Ecological Data. Biometrics 57:495-501.

FSC. 2015. FSC Principles and Criteria for Forest Stewardship. Forest Stewardship Council. Government of Quebec (Minister of Natural Resources and Wildlife). 2009. Plan Nord - For a socially responsible and sustainable form of economic development. Working document, Ressources naturelles et Faune Québec, Quebec.

Grantham, H. S., A. Duncan, T. D. Evans, K. Jones, H. Beyer, R. Schuster, J. Walston, J. Ray, J. Robinson, M. Callow, T. Clements, H. M. Costa, A. DeGemmis, P. R. Elsen, J. Ervin, P. Franco, E. Goldman, S. Goetz, A. Hansen, E. Hofsvang, P. Jantz, S. Jupiter, A. Kang, P. Langhammer, W. F. Laurance, S. Lieberman, M. Linkie, Y. Malhi, S. Maxwell, M. Mendez, R. Mittermeier, N. Murray, H. Possingham, J. Radachowsky, C. Samper, J. Silverman, A. Shapiro, B. Strassburg, T. Stevens, E. Stokes, R. Taylor, T. Tear, R. Tizard, O. Venter, P. Visconti, S. Wang, and J. E. M. Watson. 2020. Modification of forests by people means only $40 \%$ of remaining forests have high ecosystem integrity. preprint, Ecology.

Griscom, B. W., J. Adams, P. W. Ellis, R. A. Houghton, G. Lomax, D. A. Miteva, W. H. Schlesinger, D. Shoch, J. V. Siikamäki, P. Smith, P. Woodbury, C. Zganjar, A. Blackman, J. Campari, R. T. Conant, 
C. Delgado, P. Elias, T. Gopalakrishna, M. R. Hamsik, M. Herrero, J. Kiesecker, E. Landis, L. Laestadius, S. M. Leavitt, S. Minnemeyer, S. Polasky, P. Potapov, F. E. Putz, J. Sanderman, M. Silvius, E. Wollenberg, and J. Fargione. 2017. Natural climate solutions. Proceedings of the National Academy of Sciences 114:11645-11650.

Guindon, L., P. Y. Bernier, A. Beaudoin, D. Pouliot, P. Villemaire, R. J. Hall, R. Latifovic, and R. St-Amant. 2014. Annual mapping of large forest disturbances across Canada's forests using $250 \mathrm{~m}$ MODIS imagery from 2000 to 2011. Canadian Journal of Forest Research 44:1545-1554.

Haddad, N. M., L. A. Brudvig, J. Clobert, K. F. Davies, A. Gonzalez, R. D. Holt, T. E. Lovejoy, J. O. Sexton, M. P. Austin, C. D. Collins, W. M. Cook, E. I. Damschen, R. M. Ewers, B. L. Foster, C. N. Jenkins, A. J. King, W. F. Laurance, D. J. Levey, C. R. Margules, B. A. Melbourne, A. O. Nicholls, J. L. Orrock, D.-X. Song, and J. R. Townshend. 2015. Habitat fragmentation and its lasting impact on Earth's ecosystems. Science Advances 1:e1500052.

Hansen, M. C., P. V. Potapov, R. Moore, M. Hancher, S. A. Turubanova, A. Tyukavina, D. Thau, S. V. Stehman, S. J. Goetz, T. R. Loveland, A. Kommareddy, A. Egorov, L. Chini, C. O. Justice, and J. R. G. Townshend. 2013. High-Resolution Global Maps of 21st-Century Forest Cover Change. Science 342:850-854.

Hansen, M. C., S. V. Stehman, and P. V. Potapov. 2010. Quantification of global gross forest cover loss. Proceedings of the National Academy of Sciences 107:8650-8655.

Hijmans, R. J. 2016. raster: Geographic Data Analysis and Modeling.

Innes, J. L., and K. B. H. Er. 2002. Questionable Utility of the Frontier Forest Concept. BioScience 52:1095-1109.

Jacobson, A. P., J. Riggio, A. M. Tait, and J. E. M. Baillie. 2019. Global areas of low human impact ('Low Impact Areas') and fragmentation of the natural world. Scientific Reports 9:14179. 
Kennedy, C. M., J. R. Oakleaf, D. M. Theobald, S. Baruch-Mordo, and J. Kiesecker. 2019. Managing the middle: A shift in conservation priorities based on the global human modification gradient. Global Change Biology 25:811-826.

Lee, P., and S. Boutin. 2006. Persistence and developmental transition of wide seismic lines in the western Boreal Plains of Canada. Journal of Environmental Management 78:240-250.

Lee, P., and R. Cheng. 2014. Human Access in Canada's Landscapes Introduction Summary. Global Forest Watch Canada.

Lee, P. G. 2009. Caution Against Using Intact Forest-Landscapes Data at Regional Scales. Ecology and Society 14:resp1.

Lee, P., M. Hanneman, J. Gysbers, R. Cheng, and W. Smith. 2010. Atlas of Canada's Intact Forest Landscapes. Page Global Forest Watch Canada.

Leroux, S. J., M. A. Krawchuk, F. Schmiegelow, S. G. Cumming, K. Lisgo, L. G. Anderson, and M. Petkova. 2010. Global protected areas and IUCN designations: Do the categories match the conditions? Biological Conservation 143:609-616.

Leu, M., S. E. Hanser, and S. T. Knick. 2008. THE HUMAN FOOTPRINT IN THE WEST: A LARGE-SCALE ANALYSIS OF ANTHROPOGENIC IMPACTS. Ecological Applications 18:1119-1139.

Lindenmayer, D. B., J. F. Franklin, and J. Fischer. 2006. General management principles and a checklist of strategies to guide forest biodiversity conservation. Biological Conservation 131:433-445.

McCloskey, J. M., and H. Spalding. 1989. A Reconnaissance-Level Inventory of the Amount of Wilderness Remaining in the World. Ambio 18:221-227.

Melillo, J. M., X. Lu, D. W. Kicklighter, J. M. Reilly, Y. Cai, and A. P. Sokolov. 2016. Protected areas' role in climate-change mitigation. Ambio 45:133-145. 
Mittermeier, R. A., C. G. Mittermeier, T. M. Brooks, J. D. Pilgrim, W. R. Konstant, G. a B. da Fonseca, and C. Kormos. 2003. Wilderness and biodiversity conservation. Proceedings of the National Academy of Sciences of the United States of America 100:10309-13.

Mokany, K., S. Ferrier, T. D. Harwood, C. Ware, M. Di Marco, H. S. Grantham, O. Venter, A. J. Hoskins, and J. E. M. Watson. 2020. Reconciling global priorities for conserving biodiversity habitat. Proceedings of the National Academy of Sciences 117:9906-9911.

OMNR. 2013. An Introduction to the Far North Land Use Strategy Table of Contents. Ontario Ministry of Natural Resources.

Pasher, J., E. Seed, and J. Duffe. 2013. Development of boreal ecosystem anthropogenic disturbance layers for Canada based on 2008 to 2010 Landsat imagery. Canadian Journal of Remote Sensing:18.

Plumptre, A. J., D. Baisero, W. Jędrzejewski, H. Kühl, F. Maisels, J. C. Ray, E. W. Sanderson, S. Strindberg, M. Voigt, and S. Wich. 2019. Are We Capturing Faunal Intactness? A Comparison of Intact Forest Landscapes and the "Last of the Wild in Each Ecoregion." Frontiers in Forests and Global Change 2:24.

Potapov, P., M. C. Hansen, L. Laestadius, S. Turubanova, A. Yaroshenko, C. Thies, W. Smith, I. Zhuravleva, A. Komarova, S. Minnemeyer, and E. Esipova. 2017. The last frontiers of wilderness : Tracking loss of intact forest landscapes from 2000 to 2013. Science Advances:1-13.

Potapov, P., A. Yaroshenko, S. Turubanova, M. Dubinin, L. Laestadius, C. Thies, D. Aksenov, A. Egorov, Y. Yesipova, I. Glushkov, M. Karpachevskiy, A. Kostikova, A. Manisha, E. Tsybikova, and I. Zhuravleva. 2008. Mapping the world's intact forest landscapes by remote sensing. Ecology and Society 13.

Price, D. T., R. I. Alfaro, K. J. Brown, M. D. Flannigan, R. A. Fleming, E. H. Hogg, M. P. Girardin, T. Lakusta, M. Johnston, D. W. Mckenney, J. H. Pedlar, T. Stratton, R. N. Sturrock, I. D. Thompson, J. A. 
Trofymow, and L. A. Venier. 2013. Anticipating the consequences of climate change for Canada's boreal forest ecosystems. Environmental Reviews 365:322-365.

Raiter, K. G., S. M. Prober, R. J. Hobbs, and H. P. Possingham. 2017. Lines in the sand: quantifying the cumulative development footprint in the world's largest remaining temperate woodland. Landscape Ecology 32:1969-1986.

van Rensen, C. K., S. E. Nielsen, B. White, T. Vinge, and V. J. Lieffers. 2015. Natural regeneration of forest vegetation on legacy seismic lines in boreal habitats in Alberta's oil sands region. Biological Conservation 184:127-135.

Richardson, J. S., and S. Béraud. 2014. Effects of riparian forest harvest on streams: a meta-analysis. Journal of Applied Ecology 51:1712-1721.

Riggio, J., J. E. M. Baillie, S. Brumby, E. Ellis, C. M. Kennedy, J. R. Oakleaf, A. Tait, T. Tepe, D. M. Theobald, O. Venter, J. E. M. Watson, and A. P. Jacobson. 2020. Global human influence maps reveal clear opportunities in conserving Earth's remaining intact terrestrial ecosystems. Global Change Biology:gcb.15109.

Sanderson, E. W., M. Jaiteh, M. A. Levy, K. H. Redford, A. V. Wannebo, and G. Woolmer. 2002. The Human Footprint and the Last of the Wild. BioScience 52:891-904.

Schindler, D. W., and P. G. Lee. 2010. Comprehensive conservation planning to protect biodiversity and ecosystem services in Canadian boreal regions under a warming climate and increasing exploitation. Biological Conservation 143:1571-1586.

Shepherd, B., and J. Whittington. 2006. Response of Wolves to Corridor Restoration and Human Use Management. Ecology and Society 11:art1.

Smith, W., and R. Cheng. 2016. Canada's Intact Fore St Landscapes Updated To 2013. Global Forest Watch Canada. 
Team, R. C. (n.d.). R: A language and environment for statistical computing. R Foundation for Statistical Computing, Vienna.

Tilman, D., M. Clark, D. R. Williams, K. Kimmel, S. Polasky, and C. Packer. 2017. Future threats to biodiversity and pathways to their prevention. Nature 546:73-81.

Venier, L. A., I. D. Thompson, R. Fleming, J. Malcolm, I. Aubin, J. A. Trofymow, D. Langor, R. Sturrock, C. Patry, R. O. Outerbridge, S. B. Holmes, S. Haeussler, L. De Grandpré, H. Y. H. Chen, E. Bayne, A. Arsenault, and J. P. Brandt. 2014. Effects of natural resource development on the terrestrial biodiversity of Canadian boreal forests 1. Environmental Reviews 490:457-490.

Venter, O., E. W. Sanderson, A. Magrach, J. R. Allan, J. Beher, K. R. Jones, H. P. Possingham, W. F. Laurance, P. Wood, B. M. Fekete, M. A. Levy, and J. E. M. Watson. 2016. Global terrestrial Human Footprint maps for 1993 and 2009. Scientific Data 3:273-281.

Ward, M., S. Saura, B. Williams, J. P. Ramírez-Delgado, N. Arafeh-Dalmau, J. R. Allan, O. Venter, G. Dubois, and J. E. M. Watson. 2020. Just ten percent of the global terrestrial protected area network is structurally connected via intact land. Nature Communications 11:4563.

Watson, J. E. M., T. Evans, O. Venter, B. Williams, A. Tulloch, C. Stewart, I. Thompson, J. C. Ray, K. Murray, A. Salazar, C. McAlpine, P. Potapov, J. Walston, J. G. Robinson, M. Painter, D. Wilkie, C. Filardi, W. F. Laurance, R. A. Houghton, S. Maxwell, H. Grantham, C. Samper, S. Wang, L. Laestadius, R. K. Runting, G. A. Silva-Chávez, J. Ervin, and D. Lindenmayer. 2018. The exceptional value of intact forest ecosystems. Nature Ecology \& Evolution 2:599-610.

Watson, J. E. M., R. A. Fuller, A. W. T. Watson, B. G. MacKey, K. A. Wilson, H. S. Grantham, M. Turner, C. J. Klein, J. Carwardine, L. N. Joseph, and H. P. Possingham. 2009. Wilderness and future conservation priorities in Australia. Diversity and Distributions 15:1028-1036. 
Watson, J. E. M., D. F. Shanahan, M. Di Marco, J. Allan, W. F. Laurance, E. W. Sanderson, B. Mackey, and O. Venter. 2016. Catastrophic Declines in Wilderness Areas Undermine Global Environment Targets. Current Biology 26:2929-2934.

White, J. C., M. A. Wulder, T. Hermosilla, N. C. Coops, and G. W. Hobart. 2017. A nationwide annual characterization of 25 years of forest disturbance and recovery for Canada using Landsat time series. Remote Sensing of Environment 194:303-321.

Williams, B. A., O. Venter, J. R. Allan, S. C. Atkinson, J. A. Rehbein, M. S. Ward, M. D. Marco, H. S. Grantham, J. Ervin, S. Goetz, A. J. Hansen, P. Jantz, R. Pillay, S. Rodríguez-Buriticá, C. Supples, A. L. S. Virnig, and J. E. M. Watson. 2020. Change in terrestrial human footprint drives continued loss of intact ecosystems. preprint, Ecology.

Woolmer, G., S. C. Trombulak, J. C. Ray, P. J. Doran, M. G. Anderson, R. F. Baldwin, A. Morgan, and E. W. Sanderson. 2008. Rescaling the Human Footprint: A tool for conservation planning at an ecoregional scale. Landscape and Urban Planning 87:42-53.

Wulder, M. A., J. C. White, T. Han, N. C. Coops, J. A. Cardille, T. Holland, and D. Grills. 2008. Monitoring Canada's forests. Part 2: National forest fragmentation and pattern. Canadian Journal of Remote Sensing 34:22. 
bioRxiv preprint doi: https://doi.org/10.1101/2020.11.13.382101; this version posted November 17, 2020. The copyright holder for this preprint (which was not certified by peer review) is the author/funder, who has granted bioRxiv a license to display the preprint in perpetuity. It is made available under aCC-BY-NC-ND 4.0 International license.

\section{FIGURES}

Figure 1. Extent of boreal region, including boreal and boreal alpine zones, in North America (Brandt 2009). The solid black line indicates the area of intersection of the eight intactness and human influence maps while the crosshatch pattern indicates the limits of the 51 caribou ranges that make up the 2015 BEAD dataset (Pasher et al. 2013).

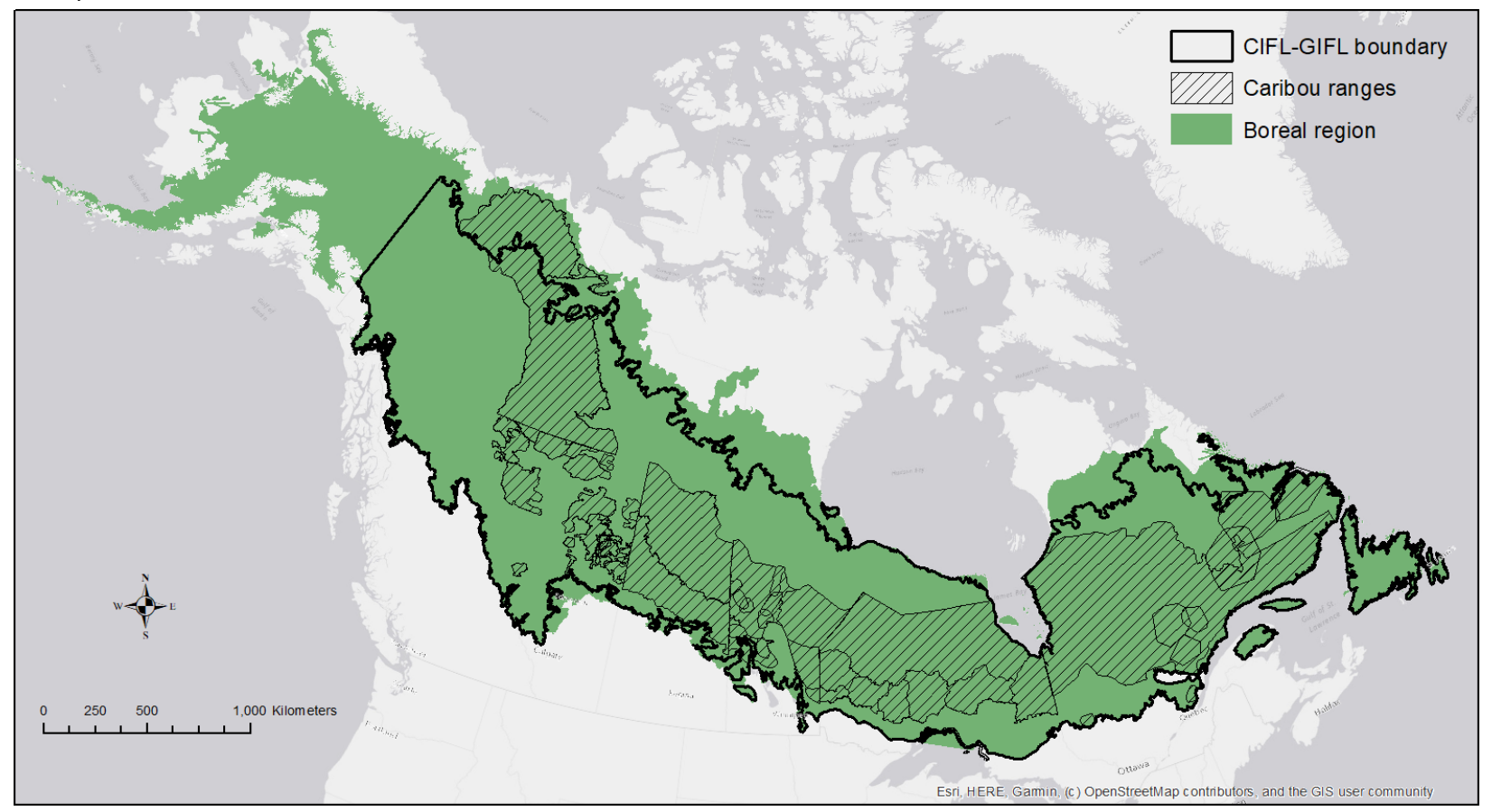


bioRxiv preprint doi: https://doi.org/10.1101/2020.11.13.382101; this version posted November 17, 2020. The copyright holder for this preprint (which was not certified by peer review) is the author/funder, who has granted bioRxiv a license to display the preprint in perpetuity. It is made available under aCC-BY-NC-ND 4.0 International license.

Figure 2. Spatial agreement between the seven most recent intactness $(N=3)$ and human influence $(N=4)$ maps. Dark green areas indicate areas identified as intact by all datasets. The percent area of agreement among: 7 maps $=45.5 \%, 6$ maps $=17.8 \%, 5$ maps $=8.8 \%, 4$ maps $=8.3 \%, 3$ maps $=6.6 \%, 2$ maps $=5.3 \%, 1$ map $=4.6 \%, 0$ maps $=3.0 \%$.

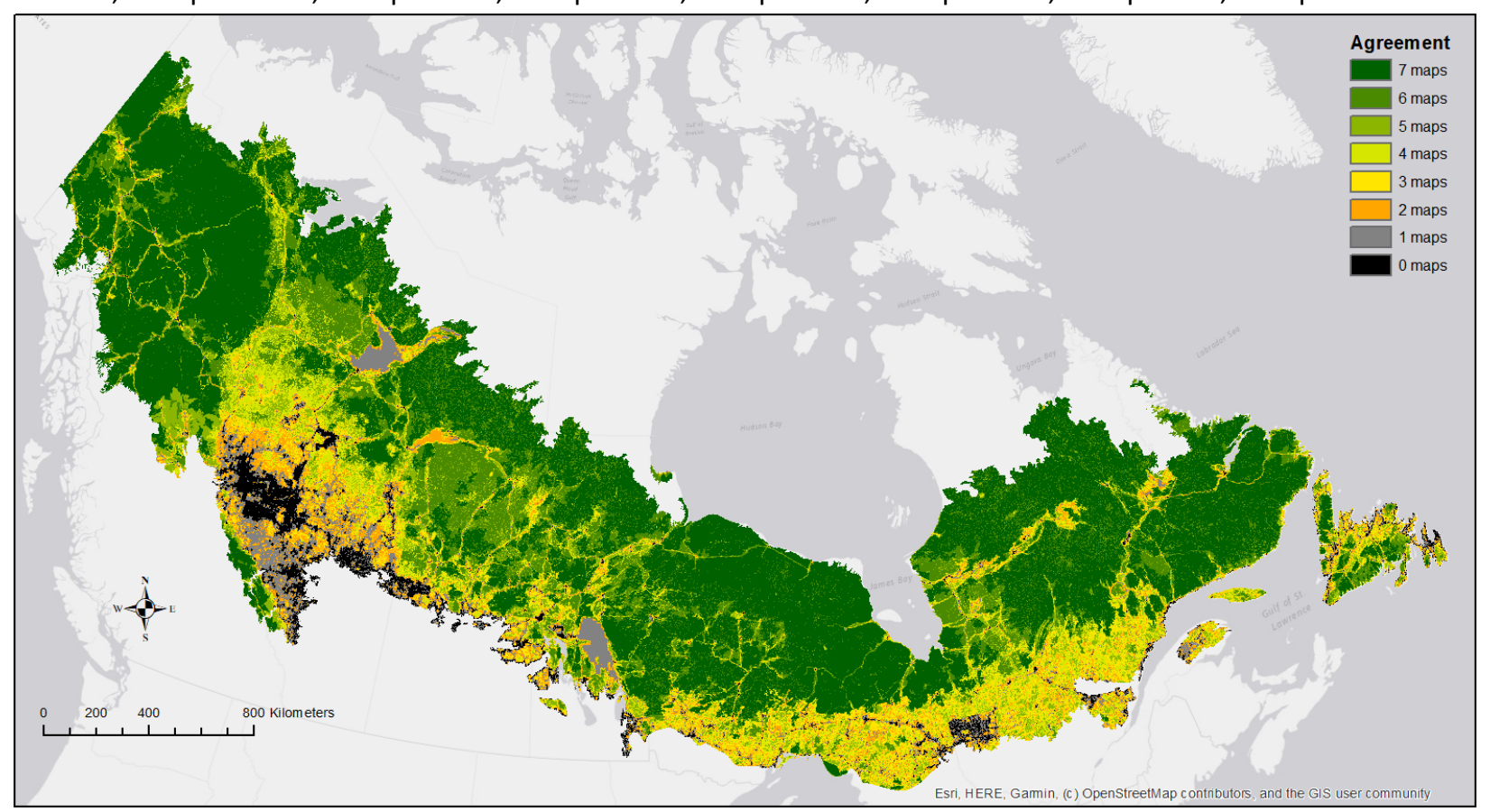


TABLES

2 Table 1. General characteristics of intactness and human influence maps reviewed in this study. Input data sources and methodological characteristics of 3 intactness and human impact maps reviewed in this study. References and links to all datasets are provided in the supporting information (S1_datasets.md).

4 Note that the Canada Human Access dataset is listed under intactness type maps since it was used as an input to the Canada IFL maps and both were produced 5 by GFWC.

\begin{tabular}{|c|c|c|c|c|c|c|c|c|c|c|}
\hline Dataset & Years $^{1}$ & $\begin{array}{l}\text { Geographic } \\
\text { extent }\end{array}$ & Format & $\begin{array}{l}\text { Scale / } \\
\text { Resolution } \\
2\end{array}$ & $\begin{array}{l}\text { Measureme } \\
\text { nt scale }\end{array}$ & $\begin{array}{l}\text { Buffer } \\
\text { distance }^{3}\end{array}$ & $\begin{array}{l}\text { Minimum patch } \\
\text { size of intact area }\end{array}$ & Reclass $^{4}$ & Thematic maps ${ }^{5}$ & Satellite imagery \\
\hline \multicolumn{11}{|c|}{ INTACTNESS TYPE MAPS } \\
\hline $\begin{array}{l}\text { Frontier } \\
\text { forests }^{8}(F F)\end{array}$ & 1996 & $\begin{array}{l}\text { Global; } \\
\text { terrestrial } \\
\text { ecosystems }\end{array}$ & Vector & $\begin{array}{l}1: 8,000,00 \\
0 \\
\left(\sim 16 \mathrm{~km}^{2}\right)\end{array}$ & $\begin{array}{l}\text { Binary; } \\
\text { frontier or } \\
\text { not frontier, } \\
\text { with threat } \\
\text { levels }\end{array}$ & $\mathrm{n} / \mathrm{a}$ & $\begin{array}{l}\text { Generally, > } \\
50,000 \text { ha }\end{array}$ & $\mathrm{n} / \mathrm{a}$ & $\begin{array}{l}\text { World Forest Map }{ }^{9} \text { and } \\
\text { Wilderness Areas map } \\
\text { (McCloskey and Spalding } \\
\text { 1989) used by }>90 \text { experts to } \\
\text { define large forested areas } \\
\text { free of roads, settlements, } \\
\text { etc. }\end{array}$ & No \\
\hline $\begin{array}{l}\text { Canada human } \\
\text { access (HA) }\end{array}$ & 2010 & $\begin{array}{l}\text { Canada; } \\
\text { terrestrial } \\
\text { ecosystems }\end{array}$ & Vector & $\begin{array}{l}1: 1,000,00 \\
0 \\
\left(\sim 0.25 \mathrm{~km}^{2}\right)\end{array}$ & $\begin{array}{l}\text { Binary; } \\
\text { human } \\
\text { access or not }\end{array}$ & $0.5 \mathrm{~km}$ & $\mathrm{n} / \mathrm{a}$ & $\begin{array}{l}\text { No human } \\
\text { access = intact }\end{array}$ & $\begin{array}{l}\text { Roads, mines, clearcuts, } \\
\text { wellsites, pipelines, } \\
\text { transmission lines, and } \\
\text { agricultural clearings }\end{array}$ & $\begin{array}{l}\text { anthropogenic } \\
\text { disturbance layers } \\
\text { (S2) }\end{array}$ \\
\hline $\begin{array}{l}\text { Boreal } \\
\text { ecosystem } \\
\text { anthropogenic } \\
\text { disturbance } \\
\text { (BEAD) }\end{array}$ & $\begin{array}{l}2010 \\
2015\end{array}$ & $\begin{array}{l}\text { Canada } \\
\text { boreal; } 51 \\
\text { caribou } \\
\text { ranges }^{10}\end{array}$ & Vector & $1: 50,000$ & $\begin{array}{l}\text { Binary; } \\
\text { human } \\
\text { access or not }\end{array}$ & unbuffered & $\mathrm{n} / \mathrm{a}$ & $\begin{array}{l}\text { No human } \\
\text { access = intact }\end{array}$ & Hydro reservoirs (GFWC) & $\begin{array}{l}\text { Landsat } 5(30-\mathrm{m} ; \\
\text { 2008-2010) and } \\
\text { Landsat } 8 \text { (15- } \\
\text { and 30-m; 2015- } \\
\text { 2017) }\end{array}$ \\
\hline $\begin{array}{l}\text { Canada intact } \\
\text { forest } \\
\text { landscapes } \\
\text { (CIFL) }\end{array}$ & $\begin{array}{l}2000 \\
2013\end{array}$ & $\begin{array}{l}\text { Canadian } \\
\text { Boreal; } 11 \\
\text { forested } \\
\text { ecozones }\end{array}$ & Vector & $\begin{array}{l}1: 1,000,00 \\
0 \\
\left(\sim 0.25 \mathrm{~km}^{2}\right)\end{array}$ & $\begin{array}{l}\text { Binary; } \\
\text { intact or not } \\
\text { intact }\end{array}$ & $\begin{array}{l}1 \mathrm{~km} \\
\text { around } \\
\text { highways; } \\
0.5 \mathrm{~km} \\
\text { around } \\
\text { other } \\
\text { disturbance } \\
\text { types }\end{array}$ & $\begin{array}{l}\text { 5,000 ha boreal \& } \\
\text { taiga ecozones; } \\
1,000 \text { ha } \\
\text { temperate } \\
\text { ecozones, which } \\
\text { occur along } \\
\text { southern edge of } \\
\text { Brandt's boreal }\end{array}$ & $\mathrm{n} / \mathrm{a}$ & $\begin{array}{l}\text { Linear features (roads, } \\
\text { cutlines, etc.), reservoirs, } \\
\text { settlements; HA2010 and } \\
\text { BEAD2010 }\end{array}$ & $\begin{array}{l}\text { Landsat 5 \& } 7 \\
(1988-2006 ; \\
\text { 28.5m); Landsat } \\
\text { composite } \\
(\sim 2013 ; 30 \mathrm{~m}) ; \\
\text { anthropogenic } \\
\text { disturbance layers } \\
\text { and forest } \\
\text { disturbance } \\
\text { dataset (S2) } \\
\end{array}$ \\
\hline $\begin{array}{l}\text { Global intact } \\
\text { forest } \\
\text { landscapes } \\
\text { (GIFL) }\end{array}$ & $\begin{array}{l}2000 \\
2013 \\
2016\end{array}$ & $\begin{array}{l}\text { Global; } \\
\text { forested } \\
\text { zones - tree } \\
\text { canopy }>20 \%\end{array}$ & Vector & $\begin{array}{l}1: 1,000,00 \\
0 \\
\left(\sim 0.25 \mathrm{~km}^{2}\right)\end{array}$ & $\begin{array}{l}\text { Binary - } \\
\text { intact or not } \\
\text { intact }\end{array}$ & $1 \mathrm{~km}$ & $\begin{array}{l}50,000 \text { ha, at least } \\
10-\mathrm{km} \text { wide at } \\
\text { broadest place, at }\end{array}$ & $\mathrm{n} / \mathrm{a}$ & $\begin{array}{l}\text { Roads, settlements, scanned } \\
\text { topographic maps }\end{array}$ & $\begin{array}{l}\text { Landsat } 5(\sim 1990 ; \\
30 \mathrm{~m}) \text { and Landsat } \\
7(\sim 2000 ; 30 \mathrm{~m}) ; \\
\text { MODIS VCF } 2000\end{array}$ \\
\hline
\end{tabular}




\begin{tabular}{|c|c|c|c|c|c|c|c|c|c|c|}
\hline & & $\begin{array}{l}\& \text { area }>4 \\
\mathrm{~km} 2 \text { (MODIS } \\
2000)\end{array}$ & & & & & $\begin{array}{l}\text { least 2-km wide in } \\
\text { corridors }\end{array}$ & & & $\begin{array}{l}\text { (percent tree } \\
\text { cover; } 0.5 \mathrm{~km} 2) ; \\
\text { Landsat } \\
\text { composite } \\
(\sim 2013 ; 30 \mathrm{~m})\end{array}$ \\
\hline \multicolumn{11}{|c|}{ HUMAN INFLUENCE TYPE MAPS } \\
\hline $\begin{array}{l}\text { Human } \\
\text { footprint }^{7} \\
\text { (HFP) }\end{array}$ & $\begin{array}{l}2000, \\
2005, \\
2010 \\
2013\end{array}$ & $\begin{array}{l}\text { Global; } \\
\text { terrestrial } \\
\text { ecosystems; } \\
\text { stratified by } \\
\text { biomes \& } \\
\text { ecoregions }\end{array}$ & Raster & $1 \mathrm{~km}^{2}$ & $\begin{array}{l}\text { Ordinal; 0-50 } \\
\text { (low to } \\
\text { high); sum of } \\
\text { ranks of } \\
\text { human } \\
\text { pressures }\end{array}$ & $\begin{array}{l}\text { Two } \\
\text { influence } \\
\text { zones: 0-2 } \\
\text { km \& 2-15 } \\
\text { km }\end{array}$ & 50,000 ha & $\begin{array}{l}H F 1993=0 ; \\
H F 2009=0\end{array}$ & $\begin{array}{l}7 \text { anthropogenic stressors } \\
\text { (human population density, } \\
\text { built-up area, cropland, } \\
\text { livestock, forest cover } \\
\text { change, roads, night-time } \\
\text { lights) }\end{array}$ & $\begin{array}{l}\text { Various including } \\
\text { global land cover } \\
\text { (GLC2000; } 1 \mathrm{~km} 2) \\
\text { and GlobCover } \\
2009(300 \mathrm{~m})\end{array}$ \\
\hline $\begin{array}{l}\text { Anthropogenic } \\
\text { biomes } \\
\text { (Anthromes, } \\
\text { AB) }\end{array}$ & $\begin{array}{l}2000, \\
2005, \\
2010, \\
2015\end{array}$ & $\begin{array}{l}\text { Global; } \\
\text { terrestrial } \\
\text { ecosystems }\end{array}$ & Raster & $\sim 5 \mathrm{~km}^{2}$ & $\begin{array}{l}\text { Categorical; } \\
6 \text { groups, } 19 \\
\text { classes }\end{array}$ & $\mathrm{n} / \mathrm{a}$ & $\mathrm{n} / \mathrm{a}$ & & $\begin{array}{l}6 \text { anthropogenic stressors } \\
\text { (human population density, } \\
\text { built-up area, cropland, rice } \\
\text { area, irrigated area, pasture) }\end{array}$ & $\begin{array}{l}\text { MODIS VCF } 2000 \\
\text { (Percent Tree } \\
\text { Cover; } 0.5 \mathrm{~km}^{2} \text { ) }\end{array}$ \\
\hline $\begin{array}{l}\text { Global human } \\
\text { modification } \\
\text { (GHM) }\end{array}$ & 2016 & $\begin{array}{l}\text { Global; } \\
\text { terrestrial } \\
\text { ecosystems }\end{array}$ & Raster & $1 \mathrm{~km}^{2}$ & $\begin{array}{l}\text { Continuous } \\
0-1 \text { (low to } \\
\text { high); } \\
\text { proportion } \\
\text { of landscape } \\
\text { modified }\end{array}$ & $\mathrm{n} / \mathrm{a}$ & $\mathrm{n} / \mathrm{a}$ & & $\begin{array}{l}13 \text { anthropogenic stressors } \\
\text { (human population density, } \\
\text { built-up area, cropland, } \\
\text { livestock, major roads, minor } \\
\text { roads, two-tracks, railroads, } \\
\text { mines, oil wells, wind } \\
\text { turbines, power lines, night- } \\
\text { time lights) }\end{array}$ & \\
\hline $\begin{array}{l}\text { Very low } \\
\text { impact areas } \\
\text { (VLIA) }\end{array}$ & 2015 & $\begin{array}{l}\text { Global; } \\
\text { terrestrial } \\
\text { ecosystems }\end{array}$ & Raster & $1 \mathrm{~km}^{2}$ & $\begin{array}{l}\text { Binary; } 2 \\
\text { classes }\end{array}$ & & & $\mathrm{n} / \mathrm{a}$ & $\begin{array}{l}7 \text { anthropogenic stressors } \\
\text { (human population density, } \\
\text { built-up area, cropland, } \\
\text { livestock, forest cover } \\
\text { change, roads, night-time } \\
\text { lights) }\end{array}$ & \\
\hline
\end{tabular}

${ }^{1}$ If the year of the dataset is not provided, we use the date of latest imagery using as input.

72 Values in brackets for vector maps indicate approximate effective grid resolution, similar to minimum mapping unit for polygonal data.

$8{ }^{3}$ The distance around disturbances that is removed from the estimation of intact areas.

$9{ }^{4}$ Map categories or values that were reclassified to indicate intactness.

$10{ }^{5}$ Human disturbances considered by the map producers; method of detection varied by map and disturbance type and included existing maps, satellite imagery and aerial

11 photos.

$12{ }^{6}$ A key intermediate dataset was GFWC's Canada Access 2010 dataset, which was created as the initial step in creating the IFL maps.

13 https://globalforestwatch.ca/sites/gfwc/files/data/20140109B_Canada_Access_2010_metadata.html

147 HFP1993 is an update to the original human footprint/human influence index dataset (circa 1993) [47]

$15{ }^{8}$ Frontier forests are large, ecologically intact, and relatively undisturbed natural forests [9] 
${ }^{9}$ The World Conservation Monitoring Centre, The World Forest Map, (WCMC, Cambridge, 1996).

1710 Partial updates to some caribou ranges in 2012. 
bioRxiv preprint doi: https://doi.org/10.1101/2020.11.13.382101; this version posted November 17,2020 . The copyright holder for this preprint (which was not certified by peer review) is the author/funder, who has granted bioRxiv a license to display the preprint in perpetuity. It is made available under aCC-BY-NC-ND 4.0 International license.

18

19

20

Table 2. Comparison of the areal extent of dataset coverage within the boreal region and areas identified as being intact within each dataset. See Supplementary Information for distribution maps of each map in Canada and Alaska.

\begin{tabular}{|c|c|c|c|c|c|c|c|c|}
\hline \multirow[b]{2}{*}{ Dataset } & \multicolumn{4}{|c|}{ Canada boreal region $\left(5,519,764 \mathrm{~km}^{2}\right)$} & \multicolumn{4}{|c|}{ Alaska boreal region $\left(737,008 \mathrm{~km}^{2}\right)$} \\
\hline & $\begin{array}{c}\text { Dataset } \\
\text { coverage } \\
\left(\mathrm{km}^{2}\right)\end{array}$ & $\begin{array}{c}\text { Coverage } \\
\text { of boreal } \\
(\%)\end{array}$ & $\begin{array}{c}\text { Intact area } \\
\left(\mathrm{km}^{2}\right)\end{array}$ & $\begin{array}{c}\text { Intact area } \\
\text { (\%) }\end{array}$ & $\begin{array}{c}\text { Dataset } \\
\text { coverage } \\
\left(\mathbf{k m}^{2}\right)\end{array}$ & $\begin{array}{c}\text { Coverage } \\
\text { of boreal } \\
(\%)\end{array}$ & $\begin{array}{c}\text { Intact area } \\
\left(\mathrm{km}^{2}\right)\end{array}$ & $\begin{array}{c}\text { Intact } \\
\text { area (\%) }\end{array}$ \\
\hline HA2010 & $5,519,764$ & 100.0 & $4,565,591$ & 82.7 & & & & \\
\hline CIFL2000 & $5,394,980$ & 97.7 & $4,029,533$ & 74.7 & & & & \\
\hline CIFL2013 & $5,394,980$ & 97.7 & $3,837,668$ & 71.1 & & & & \\
\hline GIFL2000 & $4,746,030$ & 86.0 & $2,780,919$ & 58.6 & 475,765 & 64.6 & 379,475 & 79.8 \\
\hline GIFL2013 & $4,746,030$ & 86.0 & $2,652,463$ & 55.9 & 475,765 & 64.6 & 355,012 & 74.6 \\
\hline GIFL2016 & $4,746,030$ & 86.0 & $2,619,094$ & 55.2 & 475,765 & 64.6 & 350,983 & 73.8 \\
\hline hfp2000 & $5,519,764$ & 100.0 & $4,474,868$ & 81.1 & 737,008 & 100.0 & 614,217 & 83.3 \\
\hline hfp2005 & $5,519,764$ & 100.0 & $4,481,331$ & 81.2 & 737,008 & 100.0 & 614,444 & 83.4 \\
\hline hfp2010 & $5,519,764$ & 100.0 & $4,466,114$ & 80.9 & 737,008 & 100.0 & 613,338 & 83.2 \\
\hline hfp2013 & $5,519,764$ & 100.0 & $4,464,139$ & 80.9 & 737,008 & 100.0 & 613,685 & 83.3 \\
\hline ab2000 & $5,519,764$ & 100.0 & $4,919,781$ & 89.1 & 737,008 & 100.0 & 645,668 & 87.6 \\
\hline$a b 2005$ & $5,519,764$ & 100.0 & $4,919,588$ & 89.1 & 737,008 & 100.0 & 645,668 & 87.6 \\
\hline ab2010 & $5,519,764$ & 100.0 & $4,921,931$ & 89.2 & 737,008 & 100.0 & 645,668 & 87.6 \\
\hline ab2015 & $5,519,764$ & 100.0 & $4,918,939$ & 89.1 & 737,008 & 100.0 & 645,427 & 87.6 \\
\hline GHM2016 & $5,519,764$ & 100.0 & $4,627,206$ & 83.8 & 737,008 & 100.0 & 707,686 & 96.0 \\
\hline VLIA2015 & $5,519,764$ & 100.0 & $4,166,590$ & 75.5 & 737,008 & 100.0 & 690,993 & 93.8 \\
\hline FF1996 & $5,519,764$ & 100.0 & $3,324,371$ & 60.2 & 737,008 & 100.0 & 237,657 & 32.2 \\
\hline
\end{tabular}

21 
bioRxiv preprint doi: https://doi.org/10.1101/2020.11.13.382101; this version posted November 17,2020 . The copyright holder for this preprint (which was not certified by peer review) is the author/funder, who has granted bioRxiv a license to display the preprint in perpetuity. It is made available under aCC-BY-NC-ND 4.0 International license.

23 Table 3. Proportional agreement between each pair-wise map comparisons within Canada's boreal region. Each

24 entry represents the proportion of intact area in Map A (shown in the rows) that is also mapped as intact in Map B

25 (shown in the columns). Comparisons were restricted to the area of intersection among the seven datasets

$26\left(4,732,303 \mathrm{~km}^{2}\right)$.

\begin{tabular}{|l|c|c|c|c|c|c|c|}
\hline Map & HA2010 & CIFL2013 & GIFL2016 & HFP2013 & AB2015 & GHM2016 & VLIA2015 \\
\hline HA2010 & 1 & & & & & & \\
\hline CIFL2013 & 0.85 & 1 & & & & & \\
\hline GIFL2016 & 0.67 & 0.77 & 1 & & & & \\
\hline HFP2013 & 0.81 & 0.79 & 0.65 & 1 & & & \\
\hline AB2015 & 0.80 & 0.73 & 0.59 & 0.84 & 1 & & \\
\hline GHM2016 & 0.81 & 0.77 & 0.62 & 0.83 & 0.86 & 1 & \\
\hline VLIA2015 & 0.74 & 0.70 & 0.58 & 0.75 & 0.77 & 0.84 & 1 \\
\hline
\end{tabular}

27

28 
bioRxiv preprint doi: https://doi.org/10.1101/2020.11.13.382101; this version posted November $17,2020$. The copyright holder for this preprint

(which was not certified by peer review) is the author/funder, who has granted bioRxiv a license to display the preprint in perpetuity. It is made available under aCC-BY-NC-ND 4.0 International license.

29 Table 4. Percent length and area omitted (misclassified as intact) by each intactness and reclassified human

30 influence map in the study area.

\begin{tabular}{|c|c|c|c|c|c|c|c|c|}
\hline \multirow{2}{*}{\multicolumn{2}{|c|}{ Disturbance type \& amount }} & \multicolumn{7}{|c|}{ Disturbance type omitted (\%) } \\
\hline & & \multirow{2}{*}{$\begin{array}{c}\text { HA2010 } \\
75.3\end{array}$} & \multirow{2}{*}{$\begin{array}{c}\text { CIFL2013 } \\
64.9\end{array}$} & \multirow{2}{*}{$\begin{array}{c}\text { GIFL2016 } \\
44.9\end{array}$} & \multirow{2}{*}{$\begin{array}{c}\text { HFP2013 } \\
84.2\end{array}$} & \multirow{2}{*}{$\begin{array}{c}\text { AB2015 } \\
93.4\end{array}$} & \multirow{2}{*}{$\begin{array}{c}\text { VLIA2015 } \\
76.2\end{array}$} & \multirow{2}{*}{$\begin{array}{c}\text { GHM2016 } \\
86.8\end{array}$} \\
\hline Intact area (\%) & & & & & & & & \\
\hline \multicolumn{9}{|c|}{ Landsat $30-\mathrm{m}$ resolution } \\
\hline Linear disturb & Length (km) & & & & & & & \\
\hline Airstrip & 236 & 3.0 & 2.1 & 5.2 & 42.3 & 52.0 & 59.2 & 55.3 \\
\hline Dam & 34 & 12.3 & 12.3 & 0.0 & 15.2 & 66.0 & 76.4 & 69.7 \\
\hline Pipeline & 29,925 & 0.7 & 0.1 & 0.0 & 52.9 & 37.0 & 77.9 & 51.2 \\
\hline Powerline & 14,123 & 5.0 & 3.1 & 0.1 & 44.7 & 71.1 & 80.0 & 75.1 \\
\hline Railway & 3,191 & 0.0 & 0.0 & 0.0 & 9.7 & 49.2 & 70.2 & 67.0 \\
\hline Road & 96,559 & 7.8 & 3.5 & 1.6 & 40.4 & 66.0 & 81.4 & 65.8 \\
\hline Seismic & 161,891 & 7.4 & 2.3 & 3.2 & 73.5 & 61.5 & 88.9 & 71.3 \\
\hline Unknown & 379 & 23.9 & 14.5 & 33.1 & 73.7 & 88.8 & 88.4 & 87.6 \\
\hline TOTAL & 306,338 & 6.7 & 2.5 & 2.2 & 59.0 & 60.9 & 84.8 & 67.7 \\
\hline $\begin{array}{l}\text { Polygonal } \\
\text { disturb }\end{array}$ & Area (km2) & & & & & & & \\
\hline Agriculture & 1,556 & 0.5 & 0.0 & 0.0 & 2.0 & 14.9 & 17.1 & 4.7 \\
\hline Cutblock & 75,598 & 4.9 & 0.7 & 0.1 & 56.5 & 91.4 & 56.8 & 88.1 \\
\hline Mine & 812 & 3.4 & 0.1 & 0.1 & 14.8 & 48.5 & 40.4 & 31.6 \\
\hline Oil/Gas & 167 & 1.6 & 0.3 & 0.0 & 9.8 & 46.2 & 16.5 & 9.9 \\
\hline Settlement & 851 & 1.4 & 0.7 & 0.3 & 2.3 & 20.7 & 22.0 & 9.8 \\
\hline Unknown & 117 & 6.4 & 3.4 & 0.4 & 16.2 & 60.8 & 46.9 & 36.7 \\
\hline Well site & 306 & 1.9 & 0.1 & 0.1 & 44.4 & 72.4 & 48.3 & 31.9 \\
\hline TOTAL & 79,407 & 4.7 & 0.7 & 0.1 & 54.2 & 88.5 & 55.3 & 84.6 \\
\hline \multicolumn{9}{|c|}{ Landsat $15-\mathrm{m}$ resolution } \\
\hline Linear disturb & Length (km) & & & & & & & \\
\hline Airstrip & 241 & 3.2 & 2.3 & 5.7 & 42.4 & 52.1 & 59.4 & 55.6 \\
\hline Dam & 36 & 11.6 & 11.6 & 0.0 & 15.0 & 64.9 & 77.6 & 69.5 \\
\hline Pipeline & 31,621 & 1.0 & 0.1 & 0.1 & 52.7 & 37.0 & 77.6 & 51.3 \\
\hline Powerline & 14,198 & 5.0 & 3.1 & 0.1 & 44.7 & 71.1 & 79.9 & 75.1 \\
\hline Railway & 3,247 & 0.0 & 0.0 & 0.0 & 9.6 & 48.7 & 70.2 & 66.6 \\
\hline Road & 123,945 & 12.0 & 6.2 & 2.5 & 42.8 & 67.4 & 81.6 & 66.8 \\
\hline Seismic & 272,091 & 12.3 & 4.1 & 3.2 & 71.5 & 60.3 & 87.8 & 70.7 \\
\hline Unknown & 629 & 32.1 & 21.0 & 28.0 & 73.0 & 86.2 & 86.6 & 85.4 \\
\hline TOTAL & 446,008 & 11.1 & 4.4 & 2.7 & 60.9 & 60.9 & 85.0 & 68.4 \\
\hline $\begin{array}{l}\text { Polygonal } \\
\text { disturb }\end{array}$ & Area (km2) & & & & & & & \\
\hline Agriculture & 1,557 & 0.5 & 0.0 & 0.0 & 2.0 & 15.0 & 17.1 & 4.7 \\
\hline Cutblock & 75,741 & 4.9 & 0.7 & 0.1 & 56.5 & 91.4 & 56.7 & 88.0 \\
\hline Mine & 815 & 3.5 & 0.1 & 0.1 & 14.8 & 48.6 & 40.4 & 31.6 \\
\hline Oil/Gas & 170 & 1.6 & 0.3 & 0.0 & 10.1 & 46.7 & 16.8 & 9.9 \\
\hline Settlement & 858 & 1.4 & 0.7 & 0.3 & 2.4 & 21.0 & 22.1 & 10.0 \\
\hline Unknown & 127 & 7.4 & 3.2 & 0.4 & 15.5 & 61.4 & 46.5 & 35.9 \\
\hline Well site & 326 & 2.2 & 0.1 & 0.2 & 44.4 & 72.5 & 48.6 & 32.1 \\
\hline TOTAL & 79,594 & 4.7 & 0.7 & 0.1 & 54.2 & 88.5 & 55.3 & 84.5 \\
\hline
\end{tabular}

